\title{
Estrogen is involved in hemangioma regression associated with mast cells
}

\author{
Fang Hou ${ }^{1,2,3}$, Yuemeng Dai ${ }^{3}$, Chun-Yang Fan ${ }^{4}$, James Y. Suen ${ }^{5}$ and Gresham T. Richter ${ }^{3,6^{*}}$
}

\begin{abstract}
Background: Estrogen plays a role in infantile hemangioma $(I H)$ development, but the underlying mechanism remains unclear. This study aimed to assess estrogen and estrogen receptor (ER) localization and expression levels in $\mathrm{H}$. In addition, the unexpected relationship between mast cells (MCs) and estrogen in human $\mathrm{H}$ was discussed.

Methods: $\mathbb{H}(n=29)$, vascular malformation (VMs, $n=33)$ and normal skin $(n=15)$ specimens were assessed. $\mathbb{H}$ was classified into proliferative ( $n=9$; age, $3.56 \pm 1.01$ months), early involuting ( $n=10$; age, $8.90 \pm 2.69$ months) and late involuting ( $n=10$; age, $20.10 \pm 4.93$ months) groups. Estradiol (E2), ER-a, ER- $\beta$, and tryptase (MC marker) levels were determined immunohistochemically and/or by double immunofluorescence staining. Quantification and localization of tryptase, ER-a, and E2 were assessed for each specimen.

Results: ER-a, E2, and tryptase were expressed in the cytoplasm and nucleus of MCs in $1 \mathrm{H}$. The $\mathrm{H}$ specimens showed significantly more tryptase, ER-a, and E2 positive MCs (30.6 $\pm 12.7,9.7 \pm 5.6$, and $19.8 \pm 8.7$ cells/high-power field [HPF], respectively) compared with VM specimens (9.0 $\pm 9.8,1.5 \pm 2.4$, and $2.5 \pm 4.1$ cells/HPF, respectively) and normal skin $(6.1 \pm 8.5,0.5 \pm 1.2$, and $1.9 \pm 3.4$ cells/HPF, respectively). Proliferating $\mathrm{IH}$ displayed fewer E2 positive MCs (14.0 6.3 cells/HPF) compared with early $(22.3 \pm 10.2$ cells/HPF, $P=0.023)$ and late $(22.4 \pm 6.8$ cells/HPF, $P=0.006)$ involuting specimens. In addition, proliferating $\mathrm{H}$ showed fewer tryptase positive MCs ( $24.7 \pm 10.8$ cells/HPF) compared with early involuting specimens $(35.7 \pm 15.3$ cells/HPF, $P=0.043)$. All IH specimens were ER-a positive and ER- $\beta$ negative.
\end{abstract}

Conclusions: E2 and ER-a are expressed on MCs and not on $\mathrm{IH}$ endothelial cells. Furthermore, activated MCs may be involved in $\mathrm{IH}$ regression.

Keywords: Infantile hemangioma, Mast cells, Estradiol, Estrogen receptor

\section{Background}

Infantile hemangioma ( $\mathrm{IH})$ is the most common benign tumor of infancy, with an incidence estimated at $4.5 \%$, which is higher in the female, caucasian race and low birth weight infants $[1,2]$. The natural history of IH is peculiar. It appears at birth or within the first weeks of life and it undergoes a rapid proliferation phase that lasts until the 12th months of life. Then, IH undergoes an involuting phase with a complete regression in $90 \%$ of cases by age 4 years [1]. IH's life cycle can be envisioned as a play in three overlapping acts, including

\footnotetext{
* Correspondence: gtrichter@uams.edu

${ }^{3}$ Center for the Investigation of Congenital Aberrancies of Vascular Development, Little Rock, AR, USA

${ }^{6}$ Division of Pediatric Otolaryngology, Arkansas Children's Hospital, 1 Children's Way, Little Rock, AR 72202, USA

Full list of author information is available at the end of the article
}

proliferation (proliferating phase), early involution (early involuting phase) and late involution (late involuting phase) [3]. Histologically, the proliferating phase is characterized by an abundance of rapidly dividing endothelial cells and mast cells (MCs). During early involuting phase, apoptotic bodies and MCs increase in number and capillaries begin to diminish. As an $\mathrm{IH}$ progresses to the late involuting phase, it is characterized by slowly diminishing vascular channels, MCs, and endothelial cells, which are gradually replaced by fibrofatty tissues [3-5]. However, there is no sharp dividing line between proliferation and involution. When involution patterns are more frequent than proliferation ones, IH exhibits spontaneous regression. Although the pathophysiology of proliferation and involution processes in IH remains unclear, imbalanced levels of 
angiogenic and antiangiogenic factors may contribute to these phenomena $[3,4]$.

There is also mounting evidence linking estrogens with $\mathrm{IH}$. For instance, IH incidence is up to three times more common in girls than in boys [1-6]. Previous findings revealed that serum estradiol (E2) levels in $\mathrm{IH}$ patients are fourfold higher than those of healthy children [7]. Moreover, estrogen promotes the proliferation of IH's vascular endothelial cells synergistically with vascular endothelial growth factor (VEGF) in vitro [8]. However, little is known about the presence and mechanisms of estrogen and estrogen receptor (ER) in the pathological process of $\mathrm{IH}$.

Several studies confirmed that E2 modulates MC migration and degranulation [9-11]. Moreover, MCs displayed ER on their surface, which can be activated by the binding of E2 [9]. Although MCs (tryptase positive) are found throughout the whole life cycle of IH [12], ER or E2 expression on MCs in $\mathrm{IH}$ remains unexplored.

We assume that $\mathrm{MC}$ precursors migrate into the $\mathrm{IH}$ tissue attracted by E2 and then, MCs undergo maturation and activation by E2 binding to ER expressed on MCs. Therefore, this study aimed to assess E2, ER, and tryptase expression profiles in MCs in the proliferative, early involuting and late involuting phases of $\mathrm{IH}$. Furthermore, the role of MC activation by E2 binding to ER in IH was discussed.

\section{Methods}

\section{Specimens}

This study was approved by the Institutional Review Board of the University of Arkansas for Medical Sciences. After obtaining informed consent, fresh surgical IH tissue specimens were obtained from 29 patients; vascular malformations (VMs) were obtained from 33 patients (12 lymphatic malformations, 8 venous malformations, 13 arteriovenous malformations); and normal skin with subcutaneous tissue samples were obtained from 15 patients. Specimens were from untreated patients and then, they have been fixed with $10 \%$ buffered formalin, paraffin embedded, serially cut into $4 \mu \mathrm{m}$ sections, and stained with hematoxylin-eosin (H\&E).

Histologic examination by a pathologist with experience in vascular anomalies (VAs) confirmed the diagnosis for each patient at the time of resection. All $\mathrm{IH}$ specimens were confirmed by histological assessment and positive staining for glucose transporter protein-1 (GLUT-1), a marker that immunohistochemically distinguishes IH from other VAs [3].

\section{Immunohistochemistry}

After deparaffinization and rehydration, the sections were heated to $97^{\circ} \mathrm{C}$ for $20 \mathrm{~min}$ in the presence of an antigen retrieval solution (CITRA, $\mathrm{pH}$ 6.0; Invitrogen, Carlsbad, CA) and cooled for $30 \mathrm{~min}$. To block endogenous peroxidase activity, the sections were incubated with hydrogen peroxide for $10 \mathrm{~min}$ and washed with phosphate-buffered saline (PBS, pH 7.4; Sigma-Aldrich, St Louis, MO). After pre-incubation with $2 \%$ nonfat milk for 30 min at room temperature, the sections were incubated with primary antibodies targeting Glut-1 (mouse monoclonal antibody; Abcam, Cambridge, MA; 1:200), estradiol (E2, rabbit polyclonal antibody; Millipore, Billerica, MA; 1:2000), tryptase (mouse monoclonal antibody; Abcam, Cambridge, MA; 1:200), ER-a (mouse monoclonal antibody; Thermo Fisher Scientific, Waltham, MA; 1:100), and ER- $\beta$ (rabbit polyclonal antibody; Invitrogen, Carlsbad, CA; 1:50), respectively, for $20 \mathrm{~h}$ at $4{ }^{\circ} \mathrm{C}$. Negative controls were incubated without primary antibodies. After washing with PBS, the sections were sequentially incubated with primary antibody enhancer (Thermo Fisher Scientific, Waltham, MA; $10 \mathrm{~min}$ ) and horseradish peroxidase polymer (Thermo Fisher Scientific, Waltham, MA; $15 \mathrm{~min}$ ) at room temperature. Next, the sections were incubated with diaminobenzidine (DAB; Thermo Fisher Scientific, Waltham, MA) for $3 \mathrm{~min}$ at room temperature, and counterstained with hematoxylin for $30 \mathrm{~s}$. After dehydration by graded alcohol solutions and cleaning with xylene substitute, the sections were mounted (with Permount; Thermo Fisher Scientific, Waltham, MA) and coverslipped.

\section{Double immunofluorescence labelling}

After deparaffinization and rehydration, the sections were heated to $97^{\circ} \mathrm{C}$ for $20 \mathrm{~min}$ in the presence of an antigen retrieval solution (CITRA, pH 6.0; Invitrogen, Carlsbad, CA) and cooled for $30 \mathrm{~min}$. To block the endogenous peroxidase activity, all sections were incubated with hydrogen peroxide for $10 \mathrm{~min}$ and washed with PBS-Tween. The sections were then pre-incubated with $2 \%$ nonfat milk for $30 \mathrm{~min}$ at room temperature, followed by incubation with a mixture of two primary antibodies targeting estradiol and tryptase, respectively, overnight at $4{ }^{\circ} \mathrm{C}$. After washing with PBS-Tween, the sections were incubated with a mixture of two fluorescent conjugated secondary antibodies (FITC conjugated Goat anti-Rabbit and Texas Red conjugated Goat anti-Mouse, Invitrogen, Carlsbad, CA) diluted in PBS, for $60 \mathrm{~min}$ at room temperature. Counterstaining was performed with 4',6-diamidino-2-phenylindole (DAPI, Invitrogen, Carlsbad, CA) for $20 \mathrm{~min}$ at room temperature. The sections were then washed in PBS-Tween and coverslipped using an anti-fade fluorescent mounting medium. After sealing with nail polish, the specimens were stored in the dark at $4{ }^{\circ} \mathrm{C}$.

\section{Mast cell counts (MCC) and statistical analyses}

MCs expressing tryptase, E2 and ER-a in all specimens were counted in 9 random high power fields (HPF, 400X) per sample. Counts were expressed as 
mean \pm SD. Student's t-test was used to compare group pairs. $P<0.05$ was considered statistically significant.

\section{Results}

All IH specimens were confirmed by histology and GLUT-1 positive staining (Fig. 1-a). Based on histological characteristics and patient ages, the IH specimens $(n=29)$ were divided into 3 groups: proliferative $(n=9$; $3.56 \pm 1.01$ months), early involuting $(n=10 ; 8.90 \pm$ 2.69 months $)$ and late involuting $(n=10 ; 20.10 \pm$ 4.93 months) (Table 1).

\section{Immunohistochemical findings}

To detect MCs in the specimens, immunohistochemical analysis for tryptase, a specific and sensitive MC maturation marker [10,12], was performed. Large numbers of tryptase positive cells were observed within all IH specimens. Tryptase was specifically localized in the cytoplasm of MCs (Figs. 1 and 2). Average total MCC in proliferative, early involuting, and late involuting phases were $24.7 \pm 10.8,35.7 \pm 15.3$, and $30.7 \pm 9.9$ cells/HPF, respectively. These findings suggested that $\mathrm{IH}$ in the proliferative phase contained significantly fewer tryptase positive MCs compared with early involuting specimens $(P=0.043)$ (Table 2). There was no significant difference between proliferative and late involuting phase.
To assess whether ER is expressed in $\mathrm{IH}$, we performed immunohistochemistry using anti-ER-a and ER- $\beta$ antibodies. All IH specimens were ER-a positive and ER- $\beta$ negative. In particular, ER-a was localized in the cytoplasm and nucleus of MCs but not in endothelial cells (Fig. 1-c). Average total ER-a positive cell counts per HPF in the proliferative, early involuting, and late involuting phases were $7.9 \pm 4.3,9.7 \pm 5.0$, and $11.2 \pm 6.9$, respectively. ER-a positive cell counts were not significantly different among the IH groups $(P>0.05)$ (Table 3$)$.

To detect cells expressing estrogen, immunohistochemistry staining for E2 was performed. All IH specimens were positive for E2, which was localized in the cytoplasm and nucleus of MCs, but not in endothelial cells (Figs. 1 and 2). Average total E2 positive cell counts in the proliferative, early involuting, and late involuting phases were $14.0 \pm 6.3,22.3 \pm 10.2$, and $22.4 \pm 6.8$ cells/ HPF, respectively, showing fewer E2 positive MCs in the proliferative phase compared with early and late involuting phase specimens $(P=0.023$ and $P=0.006$, respectively) (Table 4, Fig. 3).

IH specimens contained significantly more tryptase, ER-a, and E2 positive MCs $(30.6 \pm 12.7,9.7 \pm 5.6$, and $19.8 \pm 8.7$ cells/HPF, respectively) compared with VM specimens $(9.0 \pm 9.8,1.5 \pm 2.4$, and $2.5 \pm 4.1 \mathrm{cells} / \mathrm{HPF}$, respectively) and normal skin $(6.1 \pm 8.5,0.5 \pm 1.2$, and $1.9 \pm 3.4$ cells/HPF, respectively). $(P<0.05)$ (Table 5).
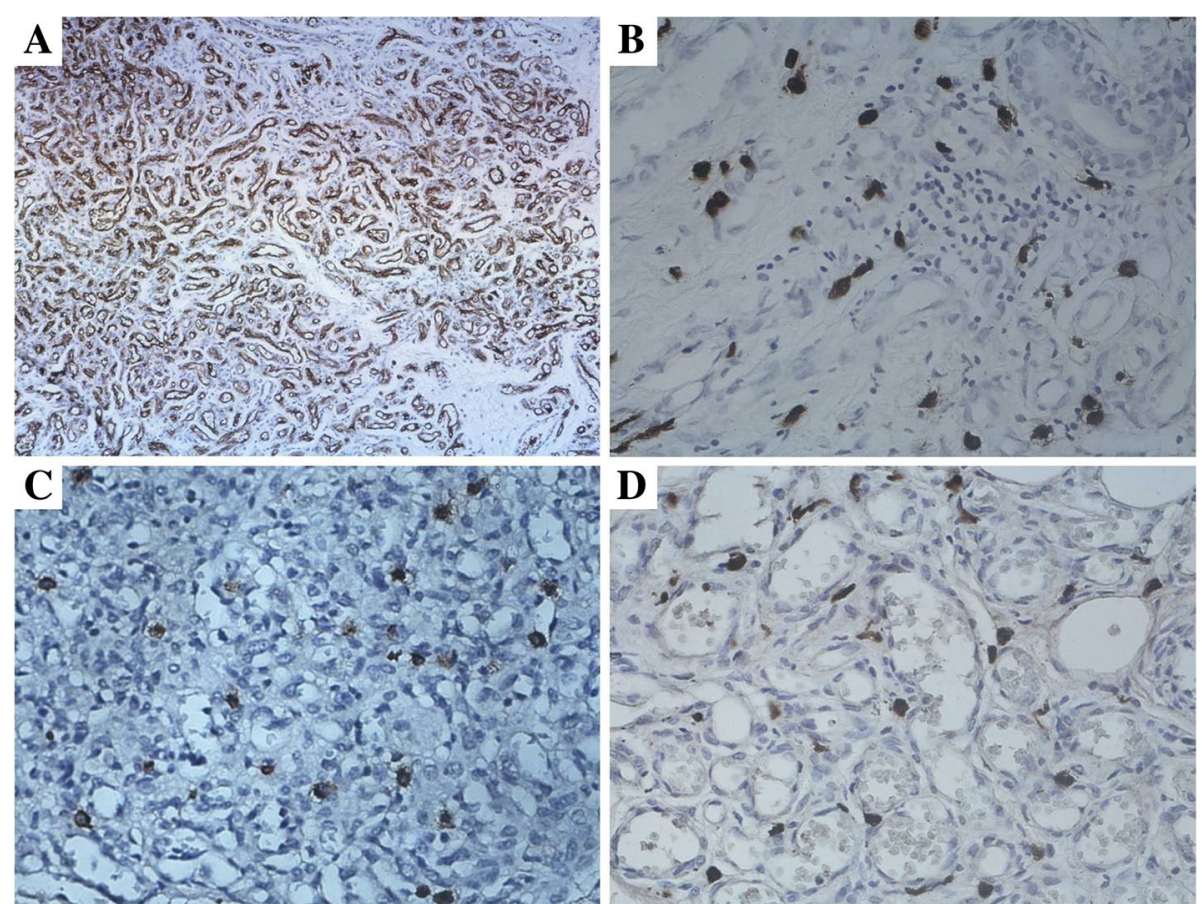

Fig. $1 \mathrm{Imm}$ unostaining for Glut-1, E2, tryptase and ER-a in IH. a All IH specimens were positive for GLUT-1, which was localized in the cytoplasm of $\mathrm{IH}$ endothelial cells $(\mathrm{IHC}, \times 100)$. Large numbers of tryptase $(\mathbf{b})$, ER-a $(\mathbf{c})$, and E2 (d) positive cells were observed in all IH specimens, specifically in the cytoplasm and nucleus of MCs, but not in $\mathrm{IH}$ endothelial cells $(\mathrm{IHC}, \times 400)$ 
Table 1 Division of $\mathrm{IH}$ specimens $(n=29)$ into 3 groups

\begin{tabular}{|c|c|c|c|c|c|}
\hline \multicolumn{2}{|c|}{$\begin{array}{l}\text { Proliferative phase, } \\
n=9\end{array}$} & \multicolumn{2}{|c|}{$\begin{array}{l}\text { Early involuting phase, } \\
n=10\end{array}$} & \multicolumn{2}{|c|}{$\begin{array}{l}\text { Late involuting phase, } \\
n=10\end{array}$} \\
\hline Age: M & Sex & Age: M & Sex & Age: $M$ & Sex \\
\hline 2 & $\mathrm{~F}$ & 6 & $\mathrm{~F}$ & 15 & $F$ \\
\hline 2 & $\mathrm{~F}$ & 6 & M & 15 & $F$ \\
\hline 3 & M & 7 & M & 15 & $F$ \\
\hline 4 & $\mathrm{~F}$ & 7 & M & 18 & $F$ \\
\hline 4 & $\mathrm{~F}$ & 7 & M & 18 & M \\
\hline 4 & F & 9 & M & 20 & M \\
\hline 4 & M & 10 & $\mathrm{~F}$ & 22 & $\mathrm{~F}$ \\
\hline 4 & $\mathrm{~F}$ & 12 & $\mathrm{~F}$ & 24 & M \\
\hline \multirow[t]{2}{*}{5} & $\mathrm{~F}$ & 12 & M & 24 & $\mathrm{~F}$ \\
\hline & & 13 & $\mathrm{~F}$ & 30 & $F$ \\
\hline \multicolumn{2}{|c|}{$3.56 \pm 1.01^{a}$} & \multicolumn{2}{|c|}{$8.90 \pm 2.69^{a}$} & \multicolumn{2}{|c|}{$20.10 \pm 4.93^{a}$} \\
\hline
\end{tabular}

The proliferative, early involuting, and late involuting phase groups were constituted

avalues are mean \pm SD months

\section{Double immunofluorescence staining}

To confirm that E2 positive cells were localized in MCs, double immunofluorescence staining for tryptase (red) and E2 (green) was performed under identical conditions for all IH sections. E2 tryptase positive cells in all IHs (Fig. 4).

\section{Discussion}

In the past 30 years, several studies have suggested that estrogens and ER may play important roles in the development of $\mathrm{IH}[6-8]$. However, little is known about the presence and the mechanisms of estrogens and ER in the pathological process of $\mathrm{IH}$. There are three major forms of physiological estrogens: estrone (E1), estradiol (E2, or 17ß-estradiol), and estriol (E3), among which, E2 is the dominant and the most effective [13]. Estrogens act through two types of receptors, including nuclear (ER-a and ER- $\beta$ ) and cell-membrane (GPR30 and ER-X) receptors. To date, however, few studies have assessed ER-a expression in $\mathrm{IH}$ tissues, indicating that estrogen may play a potential role in the development of $\mathrm{IH}$ $[7,14,15]$. In our study, MCs in IH showed strong positive staining for E2, ER-a, and tryptase, conversely E2 and ER-a were not expressed in endothelial cells.

In literature, it has been reported that the $\mathrm{MC}$ number fluctuates during the growth $\mathrm{IH}$ phases [16-19] and that highest MC count was observed during the involuting phase [18], consistent with our findings. In fact, IH in the proliferative phase contained fewer tryptase positive MCs compared with early involuting phase samples. However, Hasan et al. revealed that although the total number of MCs is highest during the early involuting phase of $\mathrm{IH}$, the proportion of proliferating $\mathrm{MC}$ is highest during the proliferative phase and lowest during the late involuting phase [19]. The mechanisms underlying $\mathrm{MC}$ presence and $\mathrm{MC}$ count alterations in $\mathrm{IH}$ remain unclear.

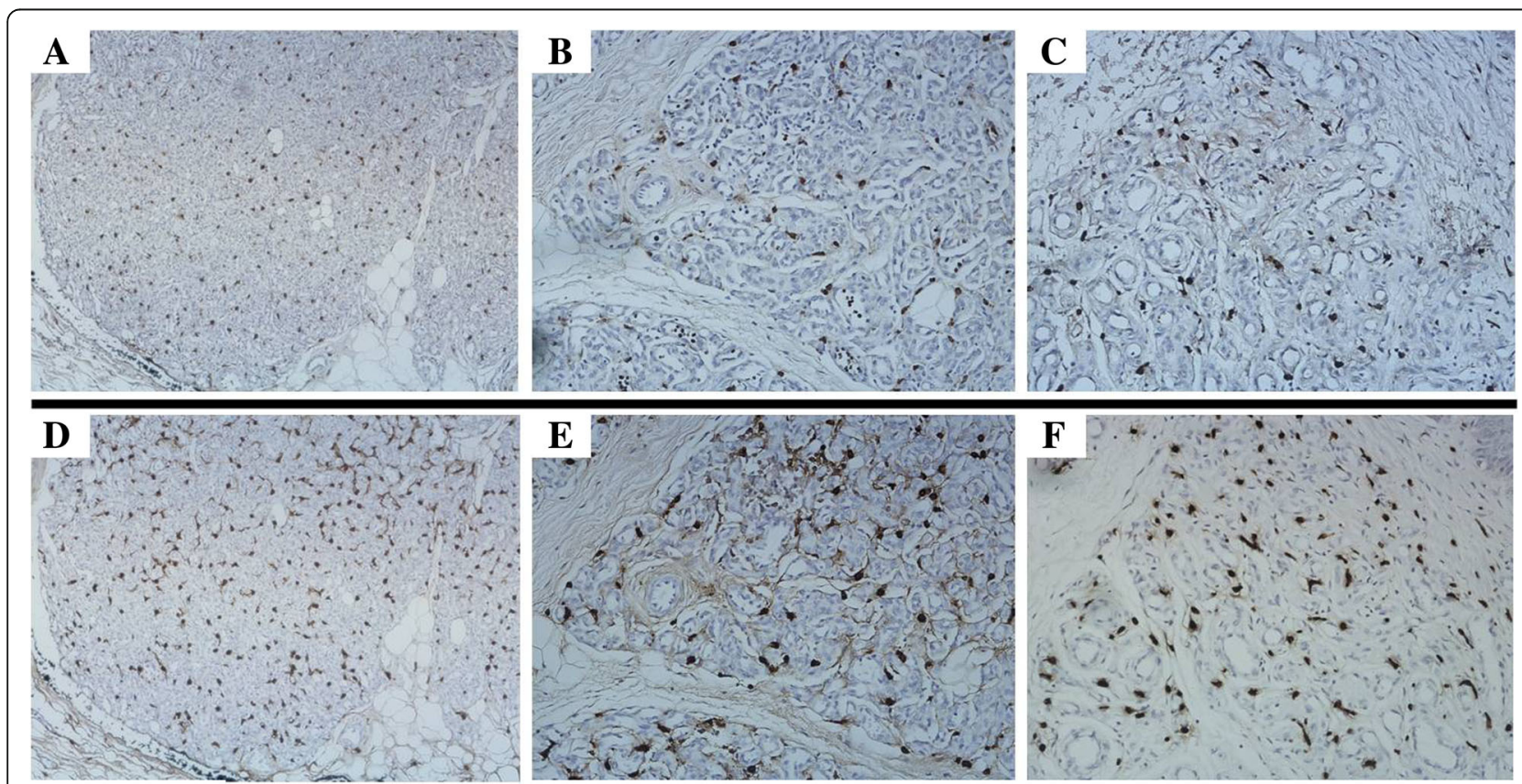

Fig. 2 Immunostaining for E2 and tryptase in $1 \mathrm{H}$. Large numbers of E2 $(\mathbf{a}, \mid H C, \times 100 ; \mathbf{b}$ and $\mathbf{c}, \mid H C, \times 200)$ and tryptase $(\mathbf{d}, I H C, \times 100 ; E$ and F, IHC, $\times 200)$ positive MCs were found within all $I H$ specimens. IH in the proliferative phase $(\mathbf{a}, \mathbf{b}, \mathbf{d}$, and $\mathbf{e})$ contained fewer E2 and tryptase positive MCs compared with early involuting phase specimens (c and $\mathbf{f})(\mathrm{HC}, \times 200)$ 
Table 2 Positive MCC in $\mathrm{IH}: \mathrm{IH}$ in the proliferative phase showed fewer tryptase positive MCs compared with early involuting phase specimens

\begin{tabular}{lll}
\hline $\begin{array}{l}\text { Proliferative phase, } \\
\text { Cells/HPF }\end{array}$ & $\begin{array}{l}\text { Early involuting } \\
\text { phase, Cells/HPF }\end{array}$ & $\begin{array}{l}\text { Late involuting } \\
\text { phase, Cells/HPF }\end{array}$ \\
\hline 21 & 34 & 23 \\
16 & 29 & 47 \\
15 & 20 & 26 \\
20 & 23 & 23 \\
25 & 45 & 33 \\
35 & 24 & 29 \\
21 & 64 & 29 \\
49 & 20 & 49 \\
20 & 53 & 20 \\
$24.7 \pm 10.8^{\text {a }}$ & 45 & 28 \\
\hline
\end{tabular}

Proliferative versus early involuting, $P=0.043$

avalues are mean \pm SD Cells/HPF

Several studies have demonstrated that E2 attracts MCs by modulating the expression of chemokine receptors on their surface and activates MCs via binding to ER-a [9-11]. Our findings that E2 exists in IH and binds to ER on MCs may provide the first evidence for E2 involvement in the regulation of $\mathrm{MC}$ migration in $\mathrm{IH}$. E2 also has an influence on MC maturation. A previous study reported that E2 significantly upregulated the expression of tryptase in the human immature mast cell line HMC-1 cells [10]. Tryptase, as a $\mathrm{MC}$ maturation marker, is the most abundant secretory granule-derived serine proteinase contained in MCs [12]. Two morphologic forms of MCs are known in $\mathrm{IH}$,

Table 3 Positive MCC in IH: ER-a positive cell counts were not different among $\mathrm{IH}$ groups

\begin{tabular}{lll}
\hline $\begin{array}{l}\text { Proliferative } \\
\text { phase, Cells/HPF }\end{array}$ & $\begin{array}{l}\text { Early involuting } \\
\text { phase, Cells/HPF }\end{array}$ & $\begin{array}{l}\text { Late involuting } \\
\text { phase, Cells/HPF }\end{array}$ \\
\hline 14 & 11 & 10 \\
9 & 9 & 18 \\
2 & 11 & 11 \\
6 & 8 & 9 \\
3 & 6 & 18 \\
4 & 9 & 7 \\
9 & 18 & 6 \\
12 & 1 & 0 \\
12 & 17 & 9 \\
$7.9 \pm 4.3^{\mathrm{a}}$ & 7 & 24 \\
\hline
\end{tabular}

No difference between these $\mathrm{IH}$ groups, $P>0.05$

avalues are mean \pm SD Cells/HPF
Table 4 Positive MCC in $\mathbb{H}$ : $\mathbb{H}$ in the proliferative phase contained fewer E2 positive MCs compared with early and late involuting phase specimens

\begin{tabular}{lll}
\hline $\begin{array}{l}\text { Proliferative } \\
\text { phase, Cells/HPF }\end{array}$ & $\begin{array}{l}\text { Early involuting } \\
\text { phase, Cells/HPF }\end{array}$ & $\begin{array}{l}\text { Late involuting } \\
\text { phase, Cells/HPF }\end{array}$ \\
\hline 13 & 38 & 17 \\
10 & 20 & 35 \\
5 & 16 & 16 \\
7 & 20 & 28 \\
18 & 19 & 28 \\
18 & 16 & 20 \\
12 & 25 & 17 \\
25 & 9 & 15 \\
18 & 42 & 20 \\
& 18 & 28 \\
$14.0 \pm 6.3^{\text {a }}$ & $22.3 \pm 10.2^{\text {a }}$ & $22.4 \pm 6.8^{\text {a }}$ \\
\hline
\end{tabular}

Proliferative versus early involuting, $P=0.023$

Proliferative versus late involuting, $P=0.006$

avalues are mean \pm SD Cells/HPF

including immature (mainly in the proliferative phase) and mature (predominantly during involution) [3]. In this study, the tryptase positive MCs were highest in the early involuting phase and lowest in the proliferative phase. Our results suggest that during the proliferative phase, $\mathrm{MC}$ precursors migrate into the $\mathrm{IH}$ tissue, attracted by $\mathrm{E} 2$, then undergo maturation and act during $\mathrm{IH}$ involution.

MCs may be activated through various mechanisms. Binding of E2 (at physiological concentrations) to a membrane ER-a initiates a rapid onset and progressive influx of extracellular $\mathrm{Ca} 2+$, which results in MC activation [9]. This type of E2 modulation in MCs requires ER-a, but not ER- $\beta$ [9, 10]; consistently, only ER-a was expressed on MCs in $\mathrm{IH}$, as shown above. In our study, MCs in IH showed strong positive staining for E2, indicating that E2 positive MCs are activated. To our knowledge, this finding provides the first evidence for the presence of activated MCs in IH.

MCs are known to secrete proangiogenic and anti-angiogenic modulators once activated, e.g. proangiogenic factors, such as histamine, tryptase and chymase, which

Table 5 Tryptase, ER-a, and E2 positive mast cells in $\mathrm{H}, \mathrm{VM}$, and normal skin samples

\begin{tabular}{llll}
\hline Specimens & $\begin{array}{l}\text { Typtase positive, } \\
\text { mean } \pm \text { SD } \\
\text { cells/HPF }\end{array}$ & $\begin{array}{l}\text { ERa positive, } \\
\text { mean } \pm \text { SD } \\
\text { cells/HPF }\end{array}$ & $\begin{array}{l}\text { E2 positive, } \\
\text { mean } \pm \text { SD } \\
\text { cells/HPF }\end{array}$ \\
\hline $\mathbb{H}(n=29)$ & $30.6 \pm 12.7$ & $9.7 \pm 5.6$ & $19.8 \pm 8.7$ \\
VMs $(n=33)$ & $9.0 \pm 9.8$ & $1.5 \pm 2.4$ & $2.5 \pm 4.1$ \\
Normal Skin $(n=15)$ & $6.1 \pm 8.5$ & $0.5 \pm 1.2$ & $1.9 \pm 3.4$ \\
\hline
\end{tabular}

IH contained significantly more Typtase, ERa and E2 positive mast cells $(p<0.05)$ 


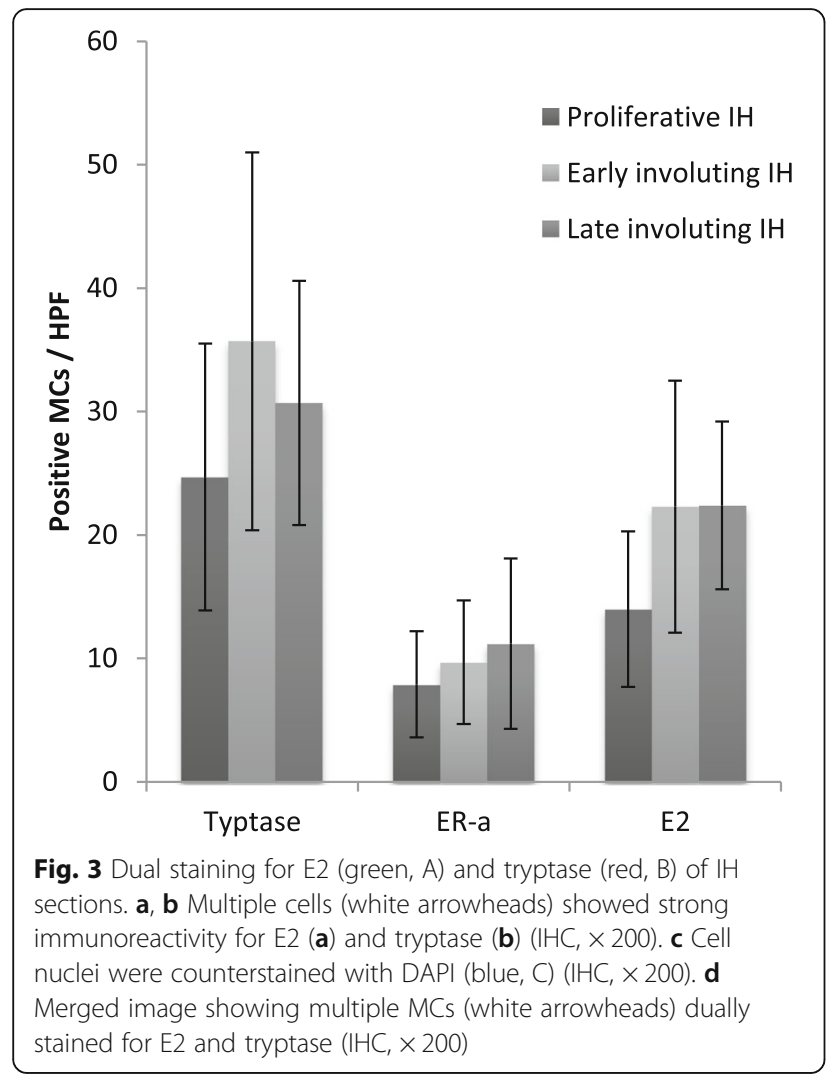

Fig. 3 Dual staining for E2 (green, A) and tryptase (red, B) of $\mathrm{HH}$ sections. a, b Multiple cells (white arrowheads) showed strong mmunoreactivity for E2 (a) and tryptase (b) $(\mathrm{IHC}, \times 200)$. c Cell Merged image showing multiple MCs (white arrowheads) dually stained for $\mathrm{E} 2$ and tryptase $(\mathrm{HC}, \times 200)$ induce angiogenesis [20-22]. Furthermore, MCs in the proliferating phase of $\mathrm{IH}$ express the angiogenic factor fibroblast growth factor (FGF)-2, which promotes endothelial cell proliferation in $\mathrm{IH}[18,23]$. Anti-angiogenic cytokines, such as interferon (IFN)-a, IFN- $\beta$, IFN- $\gamma$ and transforming growth factor (TGF) $-\beta$ [18]. IFN-a and IFN $-\beta$ can down-regulated the angiogenic factor FGF-2 $[23,24]$, while IFN- $\gamma$ inhibits the mitogenic effect of VEGF [25] (FGF-2 and VEGF are significant angiogenic factors in proliferating $\mathrm{IH}$ ) [26]. TGF- $\beta$ plays a crucial role in vascular remodeling and maturation during the angiogenic process [27]. It has been shown that TGF- $\beta$ inhibits endothelial cell proliferation and stimulates extracellular matrix deposition, while lack of TGF- $\beta$ may increase proliferation in endothelial cells [12, 27]. Ultrastructural evidence suggests that adjacent cells (e.g. fibroblasts, macrophages, multinucleated giant cells, and plasma cells) will uptake the factors released by MCs in IH [28]. However, the factors being exchanged between these cells remain unclear, as well as the number of activated MCs in IH.

Our results showed that $\mathrm{IH}$ in the early and late involuting phases contained more E2 positive MCs compared with proliferative phase specimens $(P=0.023$ and $P=0.006$, respectively), suggest that activated MCs are likely release modulators that lead to regression of neovessels in IH. Furthermore, it has been shown that after steroid therapy, the MC number in involuting $\mathrm{IH}$ increased by fourfold compared to untreated $\mathrm{IH}[29]$.
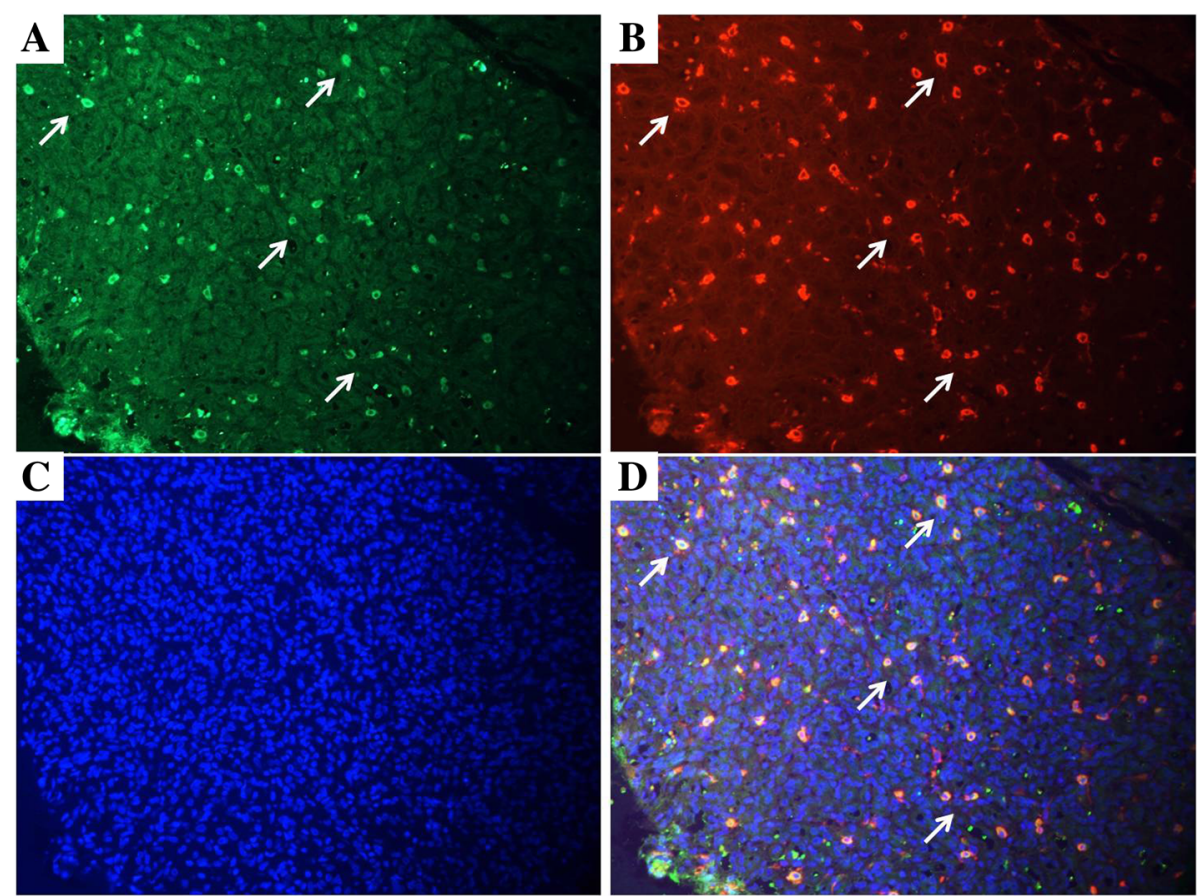

Fig. 4 Positive MCC in $\mathrm{H}$ : General patterns of positive MCC in different phases of $\mathrm{IH}$ (mean $\pm S D$ ). 
Interestingly, our results apparently contradict the proangiogenic effect of MCs. However, the fact that not all MCs showed positive staining for E2 in this study, suggest that only certain MCs, activated by E2, are involved in $\mathrm{IH}$ regression.

This study had several limitations. First, the number of surgical IH tissue specimens was limited. Second, in this research, all $\mathrm{IH}$ specimens resection was followed the $\mathrm{IH}$ surgical principles [30]. So, the specimens may not truly represent most IHs, which can be left alone, allowing the natural involution to run its course [30]. Third, the surgical specimens may not truly represent the clinical phase of $\mathrm{IH}$, because sometimes histological features of all three phases may coexist in one surgical IH tissue specimen.

\section{Conclusions}

This study firstly showed the following: (1) E2 and ER-a are expressed on MCs rather than endothelial cells in $\mathrm{IH}$; (2) E2 may regulate MC migration in IH; (3) MCs activated by E2 binding to ER-a are likely involved in $\mathrm{IH}$ regression. Although the concentrations of E2 and the molecular mechanisms underlying estrogenic effects on mediator release from activated MCs in IH need further investigation.Our findings suggest a new direction in the study of the mechanisms of estrogen interference of $\mathrm{IH}$ development via MCs.

\section{Abbreviations \\ DAB: Diaminobenzidine; DAPI: 4',6-diamidino-2-phenylindole; E2: Estradiol: ER: Estrogen receptor; FGF: Fibroblast growth factor; GLUT-1: Glucose transporter protein-1; H\&E: Hematoxylin-eosin; HPF: High power fields; IFN: Interferon; IH: Infantile hemangioma; MCC: Mast cell counts; MCs: Mast cells; PBS: Phosphate buffered saline; TGF: Transforming growth factor; VAs: Vascular anomalies; VEGF: Vascular endothelial growth factor: VMs: Vascular malformations}

\section{Acknowledgements}

Thank you Jessica Boswell for you hard work in our daily laboratory functions.

\section{Funding}

This study was supported by Arkansas biological institute grant.

\section{Availability of data and materials}

The datasets used and/or analyzed during the current study are available from the corresponding author on reasonable request.

\section{Authors' contributions}

FH and GTR conceived and designed the experiments. FH and YMD performed the experiments. FH, CYF and YMD analyzed the data. FH and YMD contributed reagents/materials/analysis tools. FH was a major contributor in writing the manuscript. GTR and JYS Critical revised the manuscript for important intellectual content. All authors read and approved the final manuscript

\section{Ethics approval and consent to participate}

This study was approved by the Institutional Review Board of the University of Arkansas for Medical Sciences.

Informed consent has obtained from 29 patients.

\section{Consent for publication}

Not applicable.

\section{Competing interests}

The authors declare that they have no competing interests.

\section{Publisher's Note}

Springer Nature remains neutral with regard to jurisdictional claims in published maps and institutional affiliations.

\section{Author details}

'Department of Pediatric Surgery, Sichuan Academy of Medical Sciences \& Sichuan Provincial People's Hospital, Chengdu 610072, China. ${ }^{2}$ School of medicine, University of Electronic Science and Technology of China, Chengdu 610072, China. ${ }^{3}$ Center for the Investigation of Congenital Aberrancies of Vascular Development, Little Rock, AR, USA. ${ }^{4}$ Department of Pathology, University of Arkansas for Medical Sciences, Little Rock, AR, USA. ${ }^{5}$ Department of Otolaryngology, University of Arkansas for Medical Sciences, Little Rock, AR, USA. ${ }^{6}$ Division of Pediatric Otolaryngology, Arkansas

Children's Hospital, 1 Children's Way, Little Rock, AR 72202, USA.

Received: 19 December 2017 Accepted: 5 October 2018

Published online: 19 October 2018

References

1. Léauté-Labrèze C, Harper Il, Hoeger PH. Infantile haemangioma. Lancet. 2017;1:85-94

2. Munden A, Butschek R, Tom WL, Marshall JS, Poeltler DM, Krohne SE, Alió $A B$, Ritter M, Friedlander DF, Catanzarite V, Mendoza A, Smith L, Friedlander M, Friedlander SF. Prospective study of infantile haemangiomas: incidence, clinical characteristics and association with placental anomalies. $\mathrm{Br} J$ Dermatol. 2014;170:907-13.

3. Mulliken JB, Bischoff J. Pathogenesis of infantile hemangioma. In: Mulliken JB, Burrows PE, Fishman SJ, editors. Vascular anomalies: hemangiomas and malformations. 2nd ed. New York: Oxford University Press; 2013. p. 43-67.

4. Tan ST, Hasan Q, Velickovic M, Ruger BM, Davis RP, Davis PF. A novel in vitro human model of hemangioma. Mod Pathol. 2000;13:92-9.

5. Darrow DH, Greene AK, Mancini AJ, Nopper AJ, Section On Dermatology, Section On Otolaryngology-Head And Neck Surgery, And Section On Plastic Surgery. Diagnosis and Management of Infantile Hemangioma. Pediatrics. 2015;136:e1060-104.

6. Chiller KG, Passaro D, Frieden IJ. Hemangiomas of infancy: clinical characteristics, morphologic subtypes, and their relationship to race, ethnicity, and sex. Arch Dermatol. 2002;138:1567-76.

7. Sasaki GH, Pang CY, Wittliff JL. Pathogenesis and treatment of infant skin strawberry hemangiomas: clinical and in vitro studies of hormonal effects. Plast Reconstr Surg. 1984;73:359-70.

8. Sun ZY, Yang L, Yi CG, Zhao H, Han DL, Yang T, Wang L, Nie CL, Zhang GY, Yin GQ, Wang G, Teng XP, Fei DM, Wang J, Zhou WK, Li Y, Liu B, Liu Y, Zhang MJ, Wu SM, Zhang X, Pan H, Xiao B, Zhao KF, Liu D, Guo SZ. Possibilities and potential roles of estrogen in the pathogenesis of proliferation hemangiomas formation. Med Hypotheses. 2008;71:286-92.

9. Zaitsu M, Narita S, Lambert KC, Grady JJ, Estes DM, Curran EM, Brooks EG, Watson CS, Goldblum RM, Midoro-Horiuti T. Estradiol activates mast cells via a non-genomic estrogen receptor-alpha and calcium influx. Mol Immunol. 2007:44:1977-85.

10. Jensen F, Woudwyk M, Teles A, Woidacki K, Taran F, Costa S, Malfertheiner $S F$, Zenclussen AC. Estradiol and progesterone regulate the migration of mast cells from the periphery to the uterus and induce their maturation and degranulation. PLoS One. 2010;5:e14409.

11. Harnish DC, Albert LM, Leathurby Y, Eckert AM, Ciarletta A, Kasaian M, Keith J. Beneficial effects of estrogen treatment in the HLA-B27 transgenic rat model of inflammatory bowel disease. Am J Physiol Gastrointest Liver Physiol. 2004;286:118-25.

12. Tan ST, Wallis RA, He Y, Davis PF. Mast cells and hemangioma. Plast Reconstr Surg. 2004;113:999-1011.

13. Cui J, Shen Y, Li R. Estrogen synthesis and signaling pathways during aging: from periphery to brain. Trends Mol Med. 2013;19:197-209.

14. Reggiani BL, Boselli F, Lupi M, Bettelli S, Schirosi L, Bigiani N, Sartori G, Rivasi $F$. Expression of estrogen receptor in hemangioma of the uterine cervix: reports of three cases and review of the literature. Arch Gynecol Obstet. 2009;280:469-72.

15. Lui W, Zhang S, Hu T, Wei F, Gao Y, Cheng N. Sex hormone receptors of hemangiomas in children. Chin Med J. 1997;110:349-51. 
16. Itinteang T, Tan ST, Jia J, Steel R, Laing EL, Brasch HD, Day DJ. Mast cells in infantile haemangioma possess a primitive myeloid phenotype. J Clin Pathol. 2013;66:597-600.

17. Steel R, Day D. Increased apoptosis and secretion of tryptase by mast cells in infantile haemangioma treated with propranolol. Pathology. 2014;46:496500.

18. Tan ST, Velickovic M, Ruger BM, Davis PF. Cellular and extracellular markers of hemangioma. Plast Reconstr Surg. 2000;106:529-38.

19. Hasan Q, Ruger BM, Tan ST, Gush J, Davis PF. Clusterin/apoJ expression during the development of hemangioma. Hum Pathol. 2000;31:691-7.

20. Caughey GH. Mast cell tryptases and chymases in inflammation and host defense. Immunol Rev. 2007;217:141-54.

21. Bosquiazzo VL, Ramos JG, Varayoud J, Munoz-de-Toro M, Luque EH. Mast cell degranulation in rat uterine cervix during pregnancy correlates with expression of vascular endothelial growth factor mRNA and angiogenesis. Reproduction. 2007;133:1045-55.

22. Norrby K. Mast cells and angiogenesis. APMIS. 2002;110:355-71.

23. Lee BS, Stewart EA, Sahakian M, Nowak RA. Interferon-alpha is a potent inhibitor of basic fibroblast growth factor-stimulated cell proliferation in human uterine cells. Am J Reprod Immunol. 1998;40:19-25.

24. Akl MR, Nagpal P, Ayoub NM, Tai B, Prabhu SA, Capac CM, Gliksman M, Goy A, Suh KS. Molecular and clinical significance of fibroblast growth factor 2 (FGF2 /bFGF) in malignancies of solid and hematological cancers for personalized therapies. Oncotarget. 2016;7:44735-62.

25. Qin Y, Zhang C. The regulatory role of IFN-gamma on the proliferation and differentiation of hematopoietic stem and progenitor cells. Stem Cell Rev. 2017. https://doi.org/10.1007/s1201501797611.

26. Itinteang T, Withers AH, Davis PF, Tan ST. Biology of infantile hemangioma. Front Surg. 2014;1:38.

27. Jonker L. TGF- $\beta$ \& BMP receptors endoglin and ALK1: overview of their functional role and status as antiangiogenic targets. Microcirculation. 2014 21:93-103.

28. Dethlefsen SM, Mulliken JB, Glowacki J. An ultrastructural study of mast cell interactions in hemangiomas. Ultrastruct Pathol. 1986;10:175-83.

29. Hasan Q, Tan ST, Gush J, Peters SG, Davis PF. Steroid therapy of a proliferating hemangioma: histochemical and molecular changes. Pediatrics. 2000:105:117-20

30. Mulliken JB. Treatment of cutaneous hemangiomas. In: Mulliken JB, Burrows PE, Fishman SJ, editors. Vascular anomalies: hemangiomas and malformations. 2nd ed. New York: Oxford University Press; 2013. p. 182-259.

Ready to submit your research? Choose BMC and benefit from:

- fast, convenient online submission

- thorough peer review by experienced researchers in your field

- rapid publication on acceptance

- support for research data, including large and complex data types

- gold Open Access which fosters wider collaboration and increased citations

- maximum visibility for your research: over $100 \mathrm{M}$ website views per year

At BMC, research is always in progress.

Learn more biomedcentral.com/submissions 